\title{
A sensitive spectrophotometric method for lead determination by flow injection analysis with on-line preconcentration
}

\author{
María S. Di Nezio, Miriam E. Palomeque, Beatriz S. Fernández Band* \\ FIA Laboratory, Department of Chemistry, Universidad Nacional del Sur, Avenida Alem 1253, 8000 Bahía Blanca, Argentina
}

Received 30 July 2003; received in revised form 6 November 2003; accepted 6 November 2003

\begin{abstract}
A new flow injection (FI) system for the determination of $\mathrm{Pb}(\mathrm{II})$ at trace level with a preconcentration step and spectrophotometric detection is proposed. It is based on preconcentration of lead ions on chitosan and dithizone-lead complex formation in aqueous medium (pH 9). The chemicals and FIA variables influencing the performance of the system were optimized and applied to the determination of lead in natural, well, and drinking water samples. It is a simple, highly sensitive, and low cost alternative methodology. The method provided a linear rage between 25 and $250 \mu \mathrm{gl}^{-1}$, a detection limit of $5.0 \mathrm{ng} \mathrm{ml}^{-1}$ and a sample throughput of $15 \mathrm{~h}^{-1}$. The obtained results of spiked samples are in good agreement between the proposed method and ICP-AES.
\end{abstract}

(c) 2003 Elsevier B.V. All rights reserved.

Keywords: Lead; Preconcentration; Spectrophotometric; FIA

\section{Introduction}

The determination of ultra traces of lead in environmental samples plays an important role in the environmental pollution monitoring, owing to its cumulative toxicity. Lead is used in storage batteries, cable sheath, solders, and radiating shielding and it is widely distributed in the nature. The environmental and health problems come fundamentally from the use of gasoline antiknock products and paint pigments [1]. It is confirmed that most of the lead contamination in humans is from foods and drinks consumed. A regular absorption of small quantities of lead may cause serious injuries to health such as encephalopathy, kidney damage and damage to the body in several other ways [2].

Electrothermal atomic absorption spectrometry (ETAAS) is the most frequently used technique for lead and others toxic trace elements determination [3-5]. Other detectors are also used such inductively coupled plasma mass spectrometry (ICP-MS) [6], hydride generation-inductively coupled plasma-atomic emission spectrometry (HG-ICP-AES) [7], with smaller frequency.

\footnotetext{
* Corresponding author. Tel.: +54-291-4595100; fax: +54-291-4595160.

E-mail address: usband@criba.edu.ar (B.S. Fernández Band).
}

The spectrophotometry detection is widely used as detection technique in FI analysis due to the low cost of the instrument, the simplicity of procedures, as well as their speed, precision, and accuracy. In literature, many chromogenic reagents have been reported for lead determination by spectrophotometric methods [8-11]. The method reported in this paper presents several advantages such as an acceptable linear rage and sample throughput, a comparable sensitivity to the most sensitive methods, lower consumption time for the analysis, a lower sample volume consumption, and that the analytical process from sample treatment is implemented on-line.

Dithizone is an old and known reagent which was widely used for heavy metal determination [12,13]. As this reagent is soluble in organic solvents, the spectrophotometric method always needed solvent-extraction techniques. Paradkar and Williams [14] proposed an aqueous/surfactant medium to prepare dithizone solution. However, there is no evidence in literature about the use of dithizone prepared through this method, probably due to the instability of the solution upon light exposure.

The aim of this paper was to develop an automatized spectrophotometric method for lead determination. The analytical method was based on dithizone-lead complex formation at $\mathrm{pH}$ 9, working in an aqueous medium. The FIA 
system was implemented in such a way that the dithizone reagent was prepared on-line, also the pretreatment of the sample for lead preconcentration and the regeneration of the mini-column was connected on-line.

\section{Experimental}

\subsection{Apparatus}

The flow assembly (Fig. 1) was provided with two Rheodyne 5041 and 5011 injection valves, two peristaltic pumps, Gilson model Minipuls 3, and an UV-V Hewlett Packard 8452A diode array spectrophotometer as detector with a Hellma 178-010-QS flow cell (inner volume, $18 \mu \mathrm{l}$ ). The reaction coils were made of PTFE tubing (i.d., $0.5 \mathrm{~mm}$ ) and the SBSR reactor (length, $6.5 \mathrm{~cm}$; i.d., $1.1 \mathrm{~mm}$ ) was made with PTFE tubing (i.d., $0.8 \mathrm{~mm}$ ) packed with glass beads (425-600 $\mu \mathrm{m})$.

\subsection{Preconcentration column}

The preconcentration column was prepared by packing a Tygon tube (i.d., $6.0 \mathrm{~cm} \times 5.0 \mathrm{~mm}$ ) with chitosan [poly(D-glucosamine)]. The ends of the tube were fitted with a piece of cigarette filter to keep the adsorbent material inside the tube.

\subsection{Reagent and solutions}

All the reagents used were of analytical grade and the solutions were prepared in distilled, deionised water.
The Triton X-100 solution (5\% v/v) was prepared by diluting $50 \mathrm{ml}$ of surfactant in $100 \mathrm{ml}$ of $1 \mathrm{M}$ hydrochloric acid, and then making up the volume to $1000 \mathrm{ml}$ with water.

Boric acid $(0.4 \mathrm{M})$ was prepared dissolving $24.74 \mathrm{~g}$ of $\mathrm{H}_{3} \mathrm{BO}_{3}$ in $1000 \mathrm{ml}$ of water.

A $2.070 \mathrm{~g} \mathrm{l}^{-1}$ lead stock solution was prepared dissolving $\mathrm{Pb}\left(\mathrm{NO}_{3}\right)_{2}$ (Riedel-de-Haën) in water. From these, working solutions were prepared as required.

\subsection{Procedure}

The FIA system is depicted in Fig. 1. The dithizone solution was obtained on-line by using a solid reagent column (SRC). This solution merged with a stream of Triton $\mathrm{X}-100(5 \% \mathrm{v} / \mathrm{v})$ in the $\mathrm{R}_{1}$ reactor in order to obtain an adequate dilution of the reagent for the forward complex formation.

The preconcentration column was incorporated in the FIA system between $V_{1}$ (six-way valve) and $V_{2}$ (selection valve). The chitosan inside the column was regenerated by passing an $\mathrm{HCl}$ solution ( $\mathrm{pH} 4$ ) in order to reach the optimum $\mathrm{pH}$ for the forward lead adsorption ( $\mathrm{pH} 7)$. The sample was loaded by passing through it for $2.5 \mathrm{~min}$, after this time a water stream ( $\mathrm{pH} \mathrm{7)}$ was passed to remove the sample still present in the line and in the column. Then, $\mathrm{V}_{1}$ valve was switched again to allow the $\mathrm{NaOH}(0.2 \mathrm{M})$ solution that went through the column to eluate the analyte. At the same time, $V_{2}$ valve was switched and the eluate merged with dithizone solution inside the reactor $\mathrm{R}_{2}$. This stream merged with a boric acid stream in the $\mathrm{R}_{3}$ reactor in order to attain the optimum medium ( $\mathrm{pH}$ 9) for dithizone-lead complex

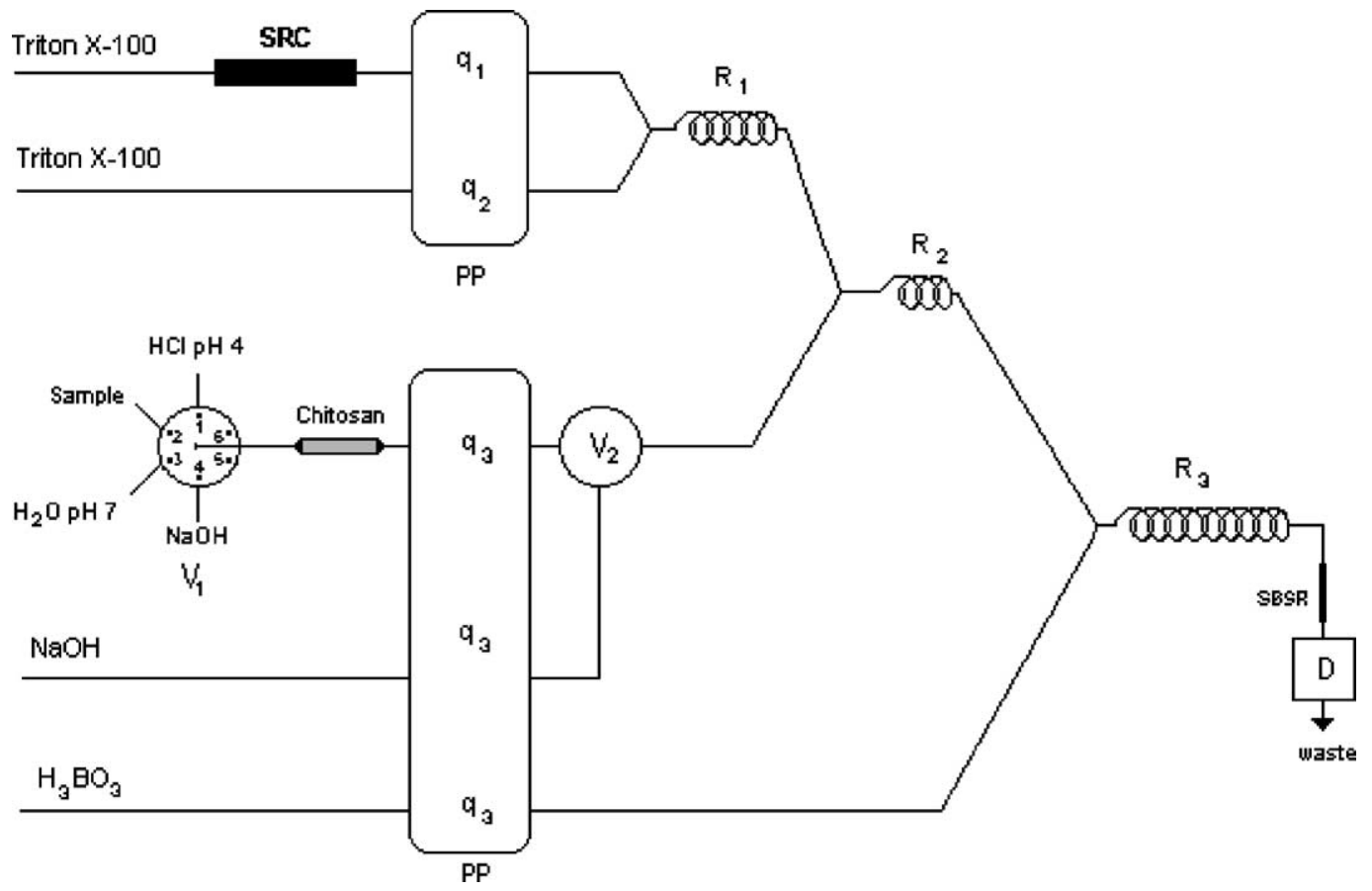

Fig. 1. PP, peristaltic pump; $\mathrm{V}_{1}$, six way valve; $\mathrm{V}_{2}$, selection valve; $\mathrm{q}_{1}$, Triton $\mathrm{X}-100$ flow rate; $\mathrm{q}_{2}$, diluent flow rate; $\mathrm{q}_{3}, \mathrm{HCl}(\mathrm{pH} 4)$; sample, water ( $\mathrm{pH}$ 7) and $\mathrm{NaOH}$ flow rates; $\mathrm{SRC}$, solid reagent column; $\mathrm{R}_{1}, \mathrm{R}_{2}$, and $\mathrm{R}_{3}$, reactors; $\mathrm{D}$, detector; SBSR, single bead string reactor. 
formation. A SBSR reactor was placed after $\mathrm{R}_{3}$ reactor to get a good base line. The complex was detected at $536 \mathrm{~nm}$.

\section{Results and discussion}

\subsection{Optimization of chemical and FIA variables}

The operational conditions of the FIA system and chemical variables were optimized in a univariant way in order to obtain the high signal and the best reproducibility. A $200 \mu \mathrm{g} 1^{-1} \mathrm{~Pb}$ standard solution was used for the optimization.

\subsubsection{Preconcentration system}

The presence of amino group in the chitosan chain does it selective for metal ions. Therefore, it confers high capacity to retain transition metals [15]. Thus, chitosan was chosen as the adsorbent material. Their characteristics were: flakes form, $3.64 \%$ moisture content, $0.71 \%$ ash, and $78.10 \%$ deacetylation degree.

The mini-column was home-made with a glass tube packed with chitosan. The column length was optimized over the range of $2.5-6.5 \mathrm{~cm}$ and the optimum results were obtained with $6 \mathrm{~cm}$. The inner diameter was tested $(2-5 \mathrm{~mm})$ and $5 \mathrm{~mm}$ was the optimum.

$\mathrm{NaOH}$ was selected for the elution of adsorbed $\mathrm{Pb}$ (II) ions, which has been reported by Lista and Fernández Band [16] and the concentration was varied between 0.15 and $0.25 \mathrm{M}$. A $0.2 \mathrm{M}$ solution was used.

A hydrochloric acid solution ( $\mathrm{pH}$ 4) was selected for chitosan regeneration [17] which give a suitable $\mathrm{pH}$ for the $\mathrm{Pb}$ (II) adsorption ( $\mathrm{pH}$ 7).

The sample and eluent flow rates, loading time and regeneration time of the column were optimized and their optimum values are shown in Table 1.

In order to evaluate the preconcentration system, the enrichment factor (EF) was calculated as the ratio of the slopes of the calibration curves, before and after the preconcentration treatment [18]. The obtained value was 8.2.

Table 1

Optimization of FIA variables

\begin{tabular}{llc}
\hline Variable & Studied range & Optimum value \\
\hline Reactor length $\mathrm{R}_{1}(\mathrm{~mm})$ & $300-900$ & 600 \\
Reactor length $\mathrm{R}_{2}(\mathrm{~mm})$ & $100-400$ & 300 \\
Reactor length $\mathrm{R}_{3}(\mathrm{~mm})$ & $600-2900$ & 1900 \\
Dithizone flow rate $\left.(\mathrm{ml} \mathrm{min})^{-1}\right)$ & $0.40-0.76$ & 0.54 \\
Triton X-100 flow rate $\left(\mathrm{ml} \mathrm{min}^{-1}\right)$ & $0.40-1.10$ & 0.76 \\
Sample flow rate $\left(\mathrm{ml} \mathrm{min}^{-1}\right)$ & $0.40-1.50$ & 1.10 \\
Eluent flow rate $\left.(\mathrm{ml} \mathrm{min})^{-1}\right)$ & $1.00-3.80$ & 1.00 \\
Loading time (min) & $1.5-3.0$ & 2.5 \\
Regeneration time $(\mathrm{s})$ & $60-120$ & 100 \\
SBSR length $(\mathrm{cm})$ & $5.0-7.5$ & 6.5 \\
SBSR inner diameter (mm) & $0.80-1.10$ & 0.80 \\
\hline
\end{tabular}

\subsubsection{FIA system}

Dithizone is soluble in Triton X-100 aqueous solution in acidic medium, but it is unstable to light exposure. Therefore, the dithizone solution was prepared on-line by using a mini-column (SRC) filled with solid dithizone and a Triton $\mathrm{X}-100$ solution passing through it. The SRC was prepared by using a dark Tygon ${ }^{\circledR}$ tube (length, $5 \mathrm{~cm}$; i.d., $3 \mathrm{~mm}$ ). Different percentages of Triton X-100 solution were tested $(1-10 \%)$ in order to obtain a suitable concentration of dithizone. The optimum value was $5 \%$.

The adequate $\mathrm{pH}$ for dithizone- $\mathrm{Pb}(\mathrm{II})$ complex formation was 9. In order to obtain this $\mathrm{pH}$ and considering that $\mathrm{NaOH}$ $0.2 \mathrm{M}$ solution was used as an eluent, a boric acid solution stream was introduced in the system. The concentration of this solution was tested between 0.2 and $0.8 \mathrm{M}$ and the best results were obtained when $0.4 \mathrm{M}$ was used.

All other FIA variables and their optimum values are listed in Table 1.

\subsection{Interferences}

The effect of potential interfering species in the determination of $50 \mu \mathrm{g}^{-1}$ of lead was studied. The levels of tolerated concentration of foreign ions was considered as maximum concentration found to cause a change in signal, less than 5\%, compared with the signal for lead alone. The tolerance limits are shown in Table 2. Some masking agents were used to remove the interference caused for metals. Thus, sodium tartrate solution $(0.16 \mathrm{M})$ to remove up $0.1 \mathrm{mg} \mathrm{l}^{-1}$ of cadmium, tiourea solution $\left(1.89 \times 10^{-2} \mathrm{M}\right)$ to eliminate the interference of mercury $\left(0.5 \mathrm{mgl}^{-1}\right)$, and sodium thiosulphate solution $(0.096 \mathrm{M})$ to eliminate copper $\left(1 \mathrm{mg} \mathrm{l}^{-1}\right)$ were used.

Table 2

Tolerance limits of interfering ions

\begin{tabular}{lc}
\hline Tested ion & Tolerance limit $\left(\mathrm{mg}^{-1}\right)$ \\
\hline $\mathrm{Cu}^{2+}$ & 0.05 (interfere) \\
$\mathrm{Hg}^{2+}$ & 1.0 (interfere) \\
$\mathrm{Cd}^{2+}$ & 0.05 (interfere) \\
$\mathrm{Zn}^{2+}$ & 2 \\
$\mathrm{Mg}^{2+}$ & 150 \\
$\mathrm{Ca}^{2+}$ & 200 \\
$\mathrm{Ni}^{2+}$ & 2 \\
$\mathrm{Fe}^{3+}$ & 0.2 (interfere) \\
$\mathrm{Na}^{+}$ & $>250$ \\
$\mathrm{~K}^{+}$ & $>500$ \\
$\mathrm{~F}^{-}$ & $>100$ \\
$\mathrm{Br}^{-}$ & $>100$ \\
$\mathrm{Cl}^{-}$ & $>900$ \\
$\mathrm{NO}_{3}{ }^{-}$ & $>800$ \\
$\mathrm{NO}_{2}{ }^{-}$ & $>60$ \\
$\mathrm{~S}^{2-}$ & 1.5 \\
$\mathrm{SO}_{4}{ }^{2-}$ & 600 \\
$\mathrm{PO}_{4}{ }^{3-}$ & $>150$ \\
$\mathrm{C}_{2} \mathrm{O}_{4}{ }^{2-}$ & $>100$ \\
$\mathrm{Humic}^{-}$acid & $>12$ \\
\hline
\end{tabular}


Table 3

Determination of $\mathrm{Pb}(\mathrm{II})$ in real samples

\begin{tabular}{|c|c|c|c|c|c|}
\hline \multirow[t]{2}{*}{ Sample } & \multirow{2}{*}{$\begin{array}{l}\mathrm{Pb}(\mathrm{II}) \text { added } \\
\left(\mu \mathrm{g} \mathrm{ml}^{-1}\right)\end{array}$} & \multicolumn{2}{|c|}{$\mathrm{Pb}(\mathrm{II})$ found $\left(\mu \mathrm{g} \mathrm{ml}^{-1}\right)^{\mathrm{a}}$} & \multicolumn{2}{|l|}{ Recovery $\pm \mathrm{s}(\%)^{\mathrm{a}}$} \\
\hline & & Proposed method & $\begin{array}{l}\text { Reference method } \\
\text { (ICP-AES) }\end{array}$ & Proposed method & $\begin{array}{l}\text { Reference method } \\
\text { (ICP-AES) }\end{array}$ \\
\hline $1-6$ & 0 & No signal & No signal & - & - \\
\hline \multirow[t]{2}{*}{1} & $\mathrm{a}$ & 0.049 & 0.005 & $98.5 \pm 0.1$ & $102.0 \pm 0.2$ \\
\hline & $\mathrm{b}$ & 0.199 & 0.197 & $99.8 \pm 0.2$ & $98.5 \pm 0.3$ \\
\hline \multirow[t]{2}{*}{2} & $\mathrm{a}$ & 0.050 & 0.048 & $100.4 \pm 0.2$ & $96.0 \pm 0.3$ \\
\hline & $\mathrm{b}$ & 0.200 & 0.202 & $100.0 \pm 0.5$ & $101.0 \pm 0.1$ \\
\hline \multirow[t]{2}{*}{3} & $\mathrm{a}$ & 0.053 & 0.055 & $107.1 \pm 0.4$ & $110.0 \pm 0.4$ \\
\hline & $\mathrm{b}$ & 0.199 & 0.203 & $99.8 \pm 0.2$ & $101.0 \pm 0.2$ \\
\hline \multirow[t]{2}{*}{4} & $\mathrm{a}$ & 0.053 & 0.051 & $106.1 \pm 0.4$ & $102.0 \pm 0.2$ \\
\hline & $\mathrm{b}$ & 0.190 & 0.205 & $95.3 \pm 0.2$ & $102.5 \pm 0.1$ \\
\hline \multirow[t]{2}{*}{5} & $\mathrm{a}$ & 0.054 & 0.055 & $108.6 \pm 0.2$ & $110.0 \pm 0.4$ \\
\hline & $\mathrm{b}$ & 0.196 & 0.198 & $98.0 \pm 0.1$ & $99.0 \pm 0.1$ \\
\hline \multirow[t]{2}{*}{6} & $\mathrm{a}$ & 0.052 & 0.048 & $105.2 \pm 0.4$ & $96.0 \pm 0.4$ \\
\hline & $\mathrm{b}$ & 0.199 & 0.202 & $99.7 \pm 0.2$ & $101.0 \pm 0.1$ \\
\hline
\end{tabular}

1: Sample of Colorado River (Paso Alsina, Río Negro State, Argentine) 2: Sample of Paso Piedras Dike, Grunbein, (Bahía Blanca, Bs. As. state, Argentine) 3: Drinking water of Bahía Blanca (Bs. As. State, Argentine) 4: Sample of Negro River (C de Patagones, Río Negro State, Argentine) 5: Sample of well water from San Cayetano (Bs. As. state, Argentine) 6: Sample of Paso Piedras Dike, B. Patagonia, (Bahía Blanca, Bs. As. State, Argentine).

a Average of three replicate determinations (a) 0.05 , (b) 0.20 .

\subsection{Analytical performance}

The calibration graph for the determination of $\mathrm{Pb}(\mathrm{II})$ was obtained under the experimental conditions above described. The results showed that a good linear relationship was observed over the range $25-250 \mu \mathrm{gl}^{-1}$. The calibration curve was $A=(0.0048 \pm 0.00036)+(0.2135 \pm$ $0.0026) \cdot\left[\mathrm{Pb}(\mathrm{II}) \mu \mathrm{g} \mathrm{ml}^{-1}\right], r^{2}=0.9996$. The detection limit estimated ( $\mathrm{S} / \mathrm{N}=3)$ was $5.0 \mathrm{ng} \mathrm{ml}^{-1} \mathrm{~Pb}(\mathrm{II})$. The repeatability of the method was calculated as the relative standard deviation (RSD) of the maximum peak heights calculated from 10 replicates containing $0.1 \mathrm{mg} \mathrm{l}^{-1} \mathrm{~Pb}$ (II) injected by duplicate and the obtained result was $4.5 \%$. The sample throughput was $15 \mathrm{~h}^{-1}$.

\subsection{Determination of lead in natural waters}

The FIA method for lead determination was validated against the ICP-AES method. As the water samples showed that lead was not present in them, they were spiked with different levels of concentrations of lead standard solution.

Sodium tartrate solution, sodium thiosulphate solution, and tiourea were added to the spiked samples, to remove the possible metals interference. Then, lead determination was carried out with the proposed method and with the alternative method. Results and recovery values are shown in Table 3.

The statistical $t$-test was used to compare the recoveries (\%) from both methods. The results revealed no significant differences between the percentages obtained and $100 \%$. Then, as both variances are equal $\left(F_{\text {calculated }}=1.18\right.$ and $\left.F_{\text {critic }(95 \%, 11)}=2.82\right)$, a comparison between recovery percentages of the proposed method and the reference method was done. The calculated $t$ is less than $t$ from the table, which shows that they were not significantly different $\left(t_{\text {calculated }}=\right.$ 0.057 and $\left.t_{\text {critic }(95 \%, 22)}=2.07\right)$ between them.

\section{Conclusions}

A new simple, highly sensitive and low cost FIA method is proposed for the determination of lead in natural, well and drinking waters. It presents good reproducibility and sample throughput. By using suitable masking agents, the method is selective.

The on-line preparation of the reagent avoids the tedious procedure of freshly preparing solution, which is unstable at light exposure. Moreover, the use of toxic organic solvents that may bring secondary pollution is not necessary, unlike the other extractive determination methods of lead $[12,13,19]$.

The preconcentration procedure is totally automatized and it is necessary low volume of sample (less than $3 \mathrm{ml}$ ) to determine lead in low levels. The detection limit is better than other previously reported [20-23].

The method was applied successfully to the analysis of different water samples. The results obtained with the proposed method are comparables with that obtained by reference method.

\section{References}

[1] B.L Carson., H.V. Ellis, J.L. McCann, Toxicology and Biological Monitoring of Metals in Humans, Lewis, Michigan, 1987.

[2] T.W Clarrkson, L. Friberg, G.F. Nordberg, P.R. Sager, Biological Monitoring of Toxic Metals, Kluwer Academic Publishers, New York, 1988. 
[3] É.C. Lima, J.L. Brasil, A.H.D.P. Santos, Anal. Chim. Acta 484 (2003) 233.

[4] J. Ančar, R. Milačil Falnoga, M.Č. Emažar, P. Bukovec, J. Pharm. Biomed. Anal. 22 (2000) 993.

[5] Z. Kiliç, O. Acar, M. Ulaşan, M. Ilim, Food Chem. 76 (2002) 107.

[6] L. Hung-Wei, J. Shiuh-Jen, L. Shin-Hung, Spectrochim. Acta Part B: At. Spectrosc. 549 (1999) 1367.

[7] S. Chen, Z. Zhang, H. Yu, W. Liu, M. Sun, Anal. Chim. Acta 463 (2002) 177.

[8] L.C. Willemsons, Handbook of Lead Chemicals, Project LC-116, International Lead Zinc Research Organization, New York, 1986.

[9] M. Xiao Chin, J. Phys. Chem. Anal. Part B: Chem. Anal. 243 (1988) 130.

[10] M. Jamaluddin Ahemed, M.A. Mamun, Talanta 55 (2001) 43-54.

[11] L. Zaijun, Y. Yuling, T. Jian, P. Jiaomai, Talanta 60 (2003) 123-130.

[12] E.A. Novikov, L.K. Shpigun, Yu.A. Zolotov, Anal. Chim. Acta 230 (1990) 157-162
[13] B. Romberg, H. Müller, Anal. Chim. Acta 353 (1997) 165.

[14] R.P. Paradkar, R.R. Williams, Anal. Chem. 66 (1994) 2752-2756.

[15] G. Rorrer, T. Hsien, J.D. Way, Ind. Eng. Chem. Res. 32 (1993) 2117.

[16] A.G. Lista, B.S. Fernández Band, Anal. Sci 15 (1999) 847.

[17] A.G. Lista, Tesis Doctoral, Universidad Nacional del Sur, Bahía Blanca, Argentina, 1988.

[18] Z. Fang, Flow Injection Separation and Preconcentration, VCH, Weinheim Germany, 1993.

[19] M.L. Rao, T.P. Iyer, C.S.P. Damodaran, Mikrochim. Acta 118 (3-4) (1995) 249-256.

[20] M.J. Ahmed, M. -Al Mamun, Talanta 55 (2001) 43.

[21] M. Luconi, M. Silva, R.A. Olsina, L. Fernandez, Talanta 54 (2001) 45.

[22] N.A. Yusof, M. Ahmad, Sens. Actuators B: Chem. 94 (2) (2003) 201-209.

[23] R.B.R. Mesquita, S.M.V. Fernandes, A.O.S. Rangel, Talanta, in press, http://www.sciencedirect.com/science/journal/00399140. 